Western University Scholarship@Western

Aboriginal Policy Research Consortium International (APRCi)

6-9-2012

\title{
Canada curbs Aboriginal health leadership
}

Paul C. Webster

Follow this and additional works at: https://ir.lib.uwo.ca/aprci

Part of the Health Policy Commons

Citation of this paper:

Webster, Paul C., "Canada curbs Aboriginal health leadership" (2012). Aboriginal Policy Research Consortium International (APRCi).

253.

https://ir.lib.uwo.ca/aprci/253 


\title{
Canada curbs Aboriginal health leadership
}

\author{
Canada has cut support for several national Aboriginal-led initiatives, leaving few Indigenous \\ people in a position to steer health policy for their communities. Paul C Webster reports.
}

Deep budget cuts to Aboriginal health groups in Canada are curbing Aboriginal leadership in confronting epidemic levels of diabetes, hypertension, HIV/AIDS, substance misuse, depression, and suicide, while reasserting government power over Aboriginal health policies and services.

In late March, Canada's Conservative Government announced austerity measures that terminated funding for the First Nations Statistical Institute, the Pauktuutit Inuit Women of Canada, the National Centre for First Nations Governance, the Aboriginal Healing Foundation, and the National Aboriginal Health Organization (NAHO), which was Canada's only organisation dedicated to developing common health policies for all of its more than 600 Aboriginal groups.

Since then, the Canadian Government has also cut health grants to the Native Women's Association of Canada, the Metis National Council, the Congress of Aboriginal Peoples, the National Indian \& Inuit Community Health Representatives Organization, and Inuit Tapiriit Kanatami (ITK), which coordinates health policies for Canada's 55000 Inuit.

Life expectancy among the Inuit is 15 years shorter than the Canadian average, with suicide rates 11 times the national average and infant mortality rates three times the national average. For Aboriginal people as a whole, infant mortality is almost $20 \%$ higher than among inhabitants in the rest of Canada, and Aboriginal people are three times more likely to have type 2 diabetes.

The cuts to Aboriginal health groups leave much of what remains of health policy development for Canada's 1.2 million Aboriginal people in the hands of federal bureaucrats who are overwhelmingly non-Aboriginal, and who have long been blamed for the historic inequities.

While curbing Aboriginal leadership in health governance, the Canadian Government is revising legislation to allow it to check Aboriginal economic and legal power. Meanwhile, the government is aggressively expediting exploitation of oil and minerals on lands claimed by Aboriginal groups.

\section{${ }^{\text {" }}$ These cuts are part of a systematic effort to dismantle} Aboriginal health groups'..."

"These cutbacks will severely reduce the ability of Inuit people to participate, even in a modest way, in the development of policies and programmes aimed at combating enormous health challenges", says Mary Simon, president of the ITK. "This is particularly unfortunate in light of the attention given by Canadian courts in recent years as to the duty of the Crown to consult closely with Aboriginal peoples and to seek to accommodate our Aboriginal rights and interests."

Simon notes that while the government imposes austerity measures on Inuit health programmes in the Arctic, Canada is increasing spending on military projects in the Arctic and promoting vast Arctic petroleum developments that will produce huge royalty streams for the government.

Leona Aglukkaq, the federal minister who directly administers almost all Aboriginal and Inuit health-care budgets, says although Aboriginal health policy organisations are being downsized, the government has not yet cut funding for core healthcare services themselves. "We will protect the front-line services of all health care services", Aglukkaq, who is herself Inuit, told the Canadian
Parliament when questioned about the termination of NAHO.

The Assembly of First Nations (AFN), Canada's largest Aboriginal governance organisation, refutes Aglukkaq's assertion, noting that recently announced cuts to the federal health department will almost certainly force cuts to Aboriginal health funding in coming months, and that major programmes including the Aboriginal Diabetes Initiative, the Aboriginal Health Human Resources Initiative, the Aboriginal Youth Suicide Prevention Strategy, the Aboriginal Health Transition Fund, the Fetal Alcohol Spectrum Disorder Program, the Maternal and Child Health Program, and the Blood Borne Diseases and Sexually Transmitted Infections/HIV/AIDS Program have recently been terminated.

The AFN argues that the rapid growth of Canada's Aboriginal population, and the growing prevalence of conditions like diabetes, hypertension, and depression, which are expensive to treat, necessitates health budget increases, rather than cuts. "These cuts are part of a systematic effort to dismantle Aboriginal health groups", says Cindy Blackstock, executive director of the Ottawa-based First Nations and Family Caring Society. After taking office in 2006, she notes, the Conservatives terminated the Kelowna Accord, a multibillion dollar pact with over 600 Aboriginal groups to bolster health and social programmes. In 2007, the government withdrew health grants from the AFN and Blackstock's group after they filed legal claims over Aboriginals health inequities. Federal officials placed Blackstock under surveillance after she initiated legal action.

\section{Paul CWebster}

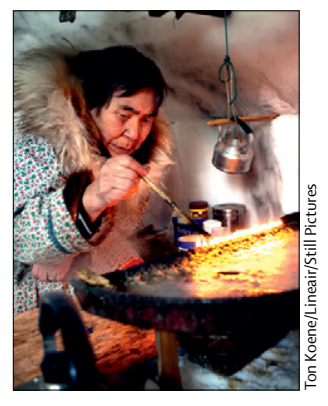

